\title{
The Application of Interactive Teaching Mode in the Ideological and Political Theory Course in Colleges and Universities
}

\author{
Li Yajuan \\ Xi'an International University, Department of Teaching and Scientific Research of Ideological and \\ Political Theory Course, Shaanxi,xian,70077, china
}

\section{Keywords: Application, Interactive Teaching Mode, Ideological Political Theory Course, Colleges} and Universities

\begin{abstract}
The ideological and political theory course of the university undertakes the task of systematic Marxist theoretical education for college students, and it is an important way to help and guide students to establish a scientific world outlook, outlook on life and values, which embodies the essence of socialist universities. The application of interactive teaching method to the teaching of ideological and political theory course in colleges and universities is a new trend of the modern teaching methods reform, and it is also an urgent need for the reform and development of the ideological and political theory course in colleges and universities in the new period.
\end{abstract}

\section{Introduction}

Interactive teaching is to promote the interaction between students and teachers and students in the classroom teaching. It is one of the common teaching modes in the modern classroom. The application of interactive teaching in the classroom teaching of ideological and political theory in colleges and universities, to get rid of the traditional classroom teaching methods to enhance the students in the classroom in the main position, conform to the requirements of quality education is an important manifestation of educational progress. Through the analysis of the present situation of ideological and political theory teaching in colleges and universities, it is concluded that it is necessary and important to adopt interactive teaching.

\section{The Overview of Interactive Teaching Mode}

Interactive teaching method has broad and narrow sense. The interactive teaching method in the broad sense refers to the interaction and influence of all related things in school teaching, including classroom interaction and extracurricular interaction, such as preparing lesson activities interaction, speaking and evaluation interaction, student work interaction, test interaction, information feedback interaction Wait. The interactive teaching method in the narrow sense refers to the interaction and influence of teachers, students and students in various forms, all kinds of nature and various degrees, which is the interaction and influence between teachers and students. I believe that interactive teaching method refers to the teaching activities, between teachers and students, students with communication, communication, cooperation, give full play to both the enthusiasm and initiative for classroom teaching to create a pleasant, sincere and harmonious to encourage students to participate in and participate in the classroom learning, to stimulate students' enthusiasm for learning, to expand the way of thinking of students to learn, so as to achieve mutual motivating and effective teaching tasks to complete the teaching method. Interactive teaching method is different from the traditional teacher-centered "indoctrination" teaching method, also different from laissez-faire students "spontaneous learning" sheep teaching method. It requires teachers to focus on student interest in learning targeted teaching, but also requires students under the careful guidance of teachers in accordance with the requirements of the teaching plan system to learn.

Interactive teaching is to adopt the interaction between teachers and students, students interact to carry out teaching, teaching activities as a communication, through a series of interactive activities to achieve the indoctrination of student knowledge, can greatly improve classroom teaching efficiency, create harmony classroom atmosphere, teachers and students in such an atmosphere are in a relaxed, 
happy state, the teaching philosophy more humane colors. The emergence of interactive teaching, to provide students with more opportunities for classroom participation, so that students become the master of the classroom, students can experience the classroom to experience the classroom, access to fresh knowledge, so as to achieve the purpose of education students. The emergence of interactive teaching gradually replaced the traditional inefficient classroom, is the embodiment of curriculum teaching model innovation, and promotes the progress of education.

\section{The Significance of the Application of the Interactive Teaching Mode in the Ideological and Political Theory Teaching in Colleges and Universities}

The course of ideological and political theory is a practical and practical course, and its teaching purpose is indispensable to the teaching of theoretical knowledge, and it is difficult to realize the traditional teaching method of indoctrination. The interactive teaching method is to observe the reality of life, pay attention to the social hotspot, focus on the problem, pay attention to cultivate students' innovative spirit and thinking ability, create an interactive space for teachers and students, so that students become the protagonist of learning, teachers and students interaction, student interaction Truth, goodness and beauty, the students have a scientific world outlook, outlook on life, values, education, and ideological and political theory of teaching with a high degree of fit, to achieve the purpose of ideological and political education.

First, the interactive teaching method is conducive to mobilize the enthusiasm and initiative of university students. Teaching activities are the bilateral activities of teachers and students. Traditional classroom teaching model only focus on teachers' "teaching", while ignoring the students "learning." Compared with the traditional classroom teaching method, the interactive teaching method has the advantage of cultivating the students 'comprehensive quality, which aims at cultivating students' thinking and solving problems. It requires the students to organize their teaching according to the teaching plan the requirements of active and active learning, but also requires teachers to reflect the students reflect the adjustment of teaching content and methods to develop students' interest in learning, improve the students hands and brain ability.

Second, interactive teaching methods help students to more rationally firm the correct political direction. In today's Internet age, college students most of the spare time is in the computer, smart phones and other cyberspace spent. As the psychological development is not yet mature, college students are easily influenced by the western multiculturalism on the network, and then question the inevitability of China's choice of the socialist road. In the classroom, it is difficult to persuade students if teachers still use the blunt, preaching-based theory of indoctrination. Only by allowing students to actively participate in interactive teaching, through multi-interaction, through the ancient and modern social system vertical and horizontal contrast, through the comparison of China's new and old society and the combination of reform and opening up the socialist modernization construction has made great achievements; Truth, reason, can really make students distinguish right from wrong, from the heart of the deep understanding and understanding to the Chinese people choose Marxism, choose the Chinese Communist Party, select the socialist road of historical necessity. This interactive teaching can not only enhance students' identity to take the road of socialism with Chinese characteristics, but also can play the role of doubts, doubts and sensible.

Third, the interactive teaching is helpful to improve the effectiveness of ideological and political theory course. Interactive teaching method is a kind of democratic, free, equal and open teaching method. It fully pays attention to the student's subjective position and makes the students participate in the teaching. Interactive teaching method can make teachers pay attention to students 'classroom learning motivation and attitude at any time, master the status of students' thought activities, communicate and explain the knowledge difficulties, doubt points and related problems, and make the classroom talk, , There is experience, so as to stimulate students interest in learning; and students interest in learning and passion affect the mood of teachers, teachers to mobilize the enthusiasm of teaching is conducive to better teaching teachers, to achieve good teaching results. At the same time, interactive teaching method can maximize the inherent potential of teachers and students, and 
actively promote the knowledge of learning and emotional exchange, to achieve teaching unity, teaching communication, teaching and learning. Practice has proved that interactive teaching can not only fully mobilize the enthusiasm and initiative of students, but also to promote the teaching of their own teaching and learning to improve the level of business. Therefore, the interactive teaching method used in the ideological and political theory course teaching, can further enhance the ideological and political theory of the attraction, appeal and effectiveness.

\section{The Specific Method of Applying the Interactive Teaching Method to the Ideological and Political Theory Teaching in Colleges and Universities}

Create a good interactive teaching environment. The interactive teaching process of the ideological and political theory course is the process of students' learning, reforming themselves and perfecting themselves in the specific situation created by their teachers. It is also the process of realizing their world outlook, values and outlook on life. A good interactive teaching environment is an important condition for the effective use of interactive teaching method. I believe that the interactive teaching environment, including classroom teaching environment and extra-curricular teaching environment, the two are interrelated, organic unity of the whole. The use of rich, the image of the emotional language, ingenious action, look to influence and attract the attention of students, so that classroom teaching content vivid image, the use of language teaching methods to create the classroom teaching environment, Students consciously become the main interactive classroom teaching, more students to stay in the classroom interaction time and space, so that students participate in the active participation in the understanding and mastery of knowledge, clarity affair, be probation. Teachers should always pay attention to the students' lectures, flexible control of the teaching process, so that students always focus on the interaction point; to maintain classroom teaching interactive discipline, grasp the classroom interaction "openness", do live, orderly. In the process of interaction to encourage the use of more oriented language, to eliminate the psychological divide between teachers and students, the "I want to learn" into "I want to learn", so that students understand the feelings in the affair, inspired, knowledge, so that their ideological realm of continuous distillation.

Extend the amount of extra-curricular interaction. Ideological and political theory course is a political, ideological, scientific and practical strong subject. In the course of ideological and political theory teaching, we must adhere to the combination of theoretical teaching and practical teaching. To change the simple classroom teaching methods, the classroom teaching, school education and social classrooms organically combine open teaching, classroom teaching and participation in social practice activities combine to further expand the extracurricular interactive information. First, make full use of modern information tools, including smart phones, computers, televisions, radio, etc., especially smart phones and computers widely used. Most of the students in addition to classes, the time spent on mobile phones and computers, they through these carriers, with the Internet, ideological and political education website, QQ, We-Chat, micro-blogging and other know and know many domestic and foreign theoretical frontiers, policies, Hot spots, focus issues, which are textbooks do not have.

Improve the overall quality of teachers in ideological and political theory courses. The ideological and political theory course is the main position and main channel of college students' acceptance system Marxism education. It has important education function, value function, knowledge education function and ability cultivation function. This particularity determines the discipline orientation of ideological and political theory course And values, the goal is to pass the ideological and political theory course teaching, so that students firmly establish a correct outlook on the world, life, values, learn to use Marxist standpoints, ideas and methods to analyze problems and solve problems, promote the harmonious development of physical and mental health of college students. Therefore, ideological and political theory teachers adhere to the "people-oriented" educational philosophy, is to be student-oriented, moral education and people-oriented. In the process of actual teaching, we should respect the students' subjective position, give play to students' 
subjective role, give the initiative to the students, adopt the teaching method which is beneficial to the students' learning and acceptance, and actively carry out the subjective ideological and political education.

Interactive pedagogy requires ideological and political theory teachers not only have a solid professional theoretical knowledge, but also understand the educational psychology, literature and art, social history and other disciplines of the basic knowledge and skills to do the next lesson, learned, But also a wealth of social practice experience, we must understand and familiar with the country's major policies, the Constitution and the relevant laws, regulations, rules and regulations, to meet the professional aspects of the actual information. Therefore, the teachers of ideological and political theory should improve their theoretical level and professional quality by means of self-study, training and training. Through continuous reflection, summarizing, exploring and improving classroom teaching methods to improve the teaching quality, try to train the modern society the need for innovative talent.

Construct incentive teaching evaluation mechanism. Incentive and evaluation is an important part of the ideological and political theory teaching in colleges and universities. It is a stimulant to arouse the initiative of all the students. It is also the source of the students' interest in learning. For a long time, due to the theoretical nature of the ideological and political theory course itself is strong, boring, abstract, some teachers in the actual teaching of the book theory, teaching and students of the ideological and life concern, guidance and help; emphasize theoretical knowledge Understanding, dilute the practical application of theory, resulting in knowledge and actions out of line, the evaluation of a single phenomenon. To this end, in the ideological and political theory course teaching in the implementation of interactive teaching, it is necessary to the original teaching evaluation methods to reform, innovation and improve the new teaching evaluation system.

\section{Conclusion}

Applying the interactive teaching method to the ideological and political theory course teaching in colleges and universities is an important way to give full play to the attraction and appeal of the ideological and political theory course teaching of the university, by giving full play to the teacher's leading and student's subjectivity, which embodies the concept of "people-oriented" scientific development concept. And it is a new discussion to further deepen the reform of ideological and political theory course under the new situation.

\section{References}

[1] B. N. Ma, A probe into multimedia interactive teaching of Marxist theory, J. Journal of Ningbo University. 44 (2010) 146-147.

[2] H.X.Zeng, The application of experiential teaching mode in the course of ideological and political theory in colleges and universities, J. Ideological Education. 18(2005) 55-57.

[3] J.H.Xue, The establishment and implementation of multi - dimensional interactive teaching, J. Higher Education Research, 32(2012) 189-190.

[4] Y.J.Qi, The application of teacher - student interaction mode in the teaching of ideological and political theory, J, Chongqing University of Technology, 4(2007) 38-40.

[5] Y.M.Tian, Research on how to put people first in ideological and political teaching in colleges and universities, J. Politics Education, 9(2013) 142-150. 